\title{
Analisa Dampak Pembuangan Limbah Pengolahan Tepung Ikan Terhadap Kualitas Air Sungai dan Ekosistem Mangrove di Sungai Kalimireng, Kecamatan Manyar, Kabupaten Gresik Miftakhul Khoiri' ${ }^{1}$, Mauludiyah ${ }^{2}$, Noverma $^{3}$
}

1,2,3Universitas Islam Negeri Sunan Ampel, Surabaya, Indonesia Mauludiyah17@gmail.com

\begin{abstract}
The existence of a fish meal processing industry operating on the banks of the Kalimireng River, Manyar Subdistrict, Gresik Regency is possible to cause environmental problems due to the risk of contamination of fish meal processing wastewater. This study aims to analyze the quality of the Kalimireng River around the fish meal processing wastewater disposal site by reviewing the physical and chemical parameters including temperature, TSS, TDS, DO, BOD, COD, and $\mathrm{pH}$ and calculate the water pollution index value. This study also analyzed the effect of disposal of fish meal processing wastewater on the mangrove ecosystem in the watershed by testing the levels of nitrogen and phosphorus contained in the sediment. The technique of sampling river water in this study was carried out by purposive sampling method. The water quality data collection point consists of three stations, (1) 50 meters before the outlet, (2) at the outlet, and (3) 50 meters after the outlet. Whereas sediment sampling is carried out in a representative sampling method. The results showed that the pollution index status in the Kalimireng River was categorized as slightly polluted with a water pollution index value of 0.05 - 8. Sediment samples taken at stations near waste disposal sites had higher nitrogen and phosphorus content than sediment samples taken at the station near the estuary. The results of observations also show that mangroves in stations near the estuary have better density and \% of coverage than mangroves in stations near waste disposal.

Keywords: fish meal wastewater, water quality, pollution index, mangrove ecosystem, Kalimireng River.
\end{abstract}

\begin{abstract}
Abstrak
Keberadaan industri pengolahan tepung ikan yang beroperasi di bantaran Sungai Kalimireng, Kecamatan Manyar, Kabupaten Gresik dimungkinkan dapat menimbulkan permasalahan lingkungan akibat resiko pencemaran limbah cair pengolahan tepung ikan. Penelitian ini bertujuan menganalisis kualitas Sungai Kalimireng di sekitar tempat pembuangan limbah cair tepung ikan dengan meninjau parameter fisika dan kimia diantaranya suhu, TSS, TDS, DO, BOD, COD, dan pH serta menghitung nilai indeks pencemaran. Penelitian ini juga menganalisis pengaruh pembuangan limbah tepung ikan terhadap ekosistem mangrove di daerah aliran sungai dengan melakukan pengujian kadar nitrogen dan fosfor yang terkandung dalam sedimen. Teknik pengambilan sampel air sungai dalam penelitian ini dilakukan dengan purposive sampling method. Titik pengambilan data kualitas air terdiri dari tiga stasiun, yaitu (1) 50 meter sebelum outlet, (2) tepat pada outlet limbah, dan (3) 50 meter setelah outlet limbah. Sedangkan pengambilan sampel sedimen dilakukan secara representatif. Hasil penelitian menunjukkan bahwa status indeks pencemaran yang ada di Sungai Kalimireng dikategorikan sebagai pencemaran ringan dengan nilai indeks pencemaran kualitas air 0,05 - 8. Sampel sedimen yang diambil di stasiun dekat lokasi pembuangan limbah memiliki kandungan nitrogen dan fosfor lebih tinggi dibanding dengan sampel sedimen yang diambil di stasiun dekat muara. Hasil pengamatan menunjukkan bahwa mangrove di stasiun dekat muara memiliki kerapatan dan \%tutupan yang lebih baik dibanding mangrove di stasiun dekat pembuangan limbah.

Kata Kunci: limbah cair tepung ikan, kualitas air, indeks pencemaran, ekosistem mangrove, Sungai Kalimireng.
\end{abstract}

\section{PENDAHULUAN}

Sungai merupakan komponen yang penting bagi kelangsungan makhluk hidup terutama manusia. Keberadaan sungai memiliki peran yang cukup vital sebagai ekosistem penyokong keberlangsungan hidup biota di sekitarnya, termasuk tumbuhan dan hewan 
yang ada di dalamnya maupun sekitarnya seperti mangrove yang hidup di daerah aliran sungai. Sungai dikatakan tercemar jika kualitas airnya tidak sesuai dengan peruntukannya. Kualitas air ini didasarkan pada baku mutu kualitas air sesuai kelas sungai berdasarkan Peraturan Pemerintah Nomor 82 Tahun 2001 tentang Pengelolaan Kualitas Air dan Pengendalian Pencemaran Air.

Pembuangan limbah industri ke sungai menjadi salah satu penyebab buruknya kondisi lingkungan di sekitar Sungai Kalimireng Kecamatan Manyar, Kabupaten Gresik, dan juga daerah aliran sungai yang banyak ditumbuhi mangrove. Hal ini terlihat dari kondisi sungai serta daerah aliran sungai di wilayah tersebut yang keruh dan berbau. Pabrik tepung ikan yang berlokasi di sekitar bantaran Sungai Kalimireng dalam proses produksinya menghasilkan limbah berupa air bekas memasak kepala ikan, yang memungkinkan mengandung serat-serat ikan yang tertinggal dan minyak ikan yang terikut didalamnya. Pembuangan limbah tersebut dilakukan secara langsung ke daerah aliran Sungai Kalimireng tanpa diolah terlebih dahulu.

Air buangan industri tersebut berpotensi sebagai bahan pencemar yang dapat mengakibatkan turunnya kualitas air di wilayah tersebut. Menurut Effendi (2003) dalam Irwanto (2011), kualitas air dinyatakan dengan beberapa parameter fisika seperti suhu, kekeruhan, warna, bau, dan TDS serta parameter kimia seperti $\mathrm{pH}$, COD, BOD, zat organik dan kesadahan. Dengan demikian perlu dilakukan sebuah penelitian yang bertujuan untuk mengetahui kualitas air Sungai Kalimireng di sekitar lokasi pembuangan limbah cair tepung ikan. Selain itu penelitian ini juga bertujuan untuk mengetahui kondisi ekosistem mangrove di sekitar pembuangan limbah cair tepung ikan.

\section{METODE PENELITIAN}

Pengambilan sampel kualitas air dilakukan dengan metode purposive sampling. Titik pengambilan sampel kualitas air terdiri dari tiga stasiun, yaitu 50 meter sebelum outlet (Stasiun 1), tepat pada outlet limbah (Stasiun 2), dan 50 meter setelah outlet limbah (Stasiun 3). Pada masing-masing stasiun dilakukan tiga kali pengulangan pengambilan data.
Selanjutnya dilakukan pengukuran parameter fisik perairan meliputi suhu, padatan tersuspensi (total suspended solids/TSS), dan padatan terlarut (total dissolved solids/TDS) serta parameter kimia perairan meliputi $\mathrm{pH}$, oksigen terlarut (dissolved oxygen/DO), biological oxygen demand (BOD), dan chemical oxygen demand (COD).

Analisis data kualitas air dalam penelitian ini dilakukan dengan menggunakan teknik komparatif yaitu dengan cara membandingkan kualitas air hasil pengukuran dengan kriteria baku mutu air dalam Peraturan Pemerintah No. 82 tanggal tahun 2001 tentang Pengelolaan Kualitas Air dan Pengendalian Pencemaran Air.

Selain itu, dalam penelitian ini juga ditentukan status mutu air Sungai Kalimireng dengan menggunakan metode Indeks Pencemaran mengacu pada Keputusan Menteri Negara Lingkungan Hidup Nomor 115 Tahun 2003 tentang Pedoman Penentuan Status Mutu Air (Tabel 1). Metode ini menghubungkan tingkat pencemaran suatu perairan yang dipakai untuk peruntukan tertentu dengan nilai parameter-parameter tertentu.

Tabel 1. Indeks Pencemaran

\begin{tabular}{cc}
\hline Nilai IP & Mutu Perairan \\
\hline $0-1,0$ & Kondisi baik \\
$1,1-5,0$ & Cemar Ringan \\
$5,0-10,0$ & Cemar sedang \\
$>10,0$ & Cemar berat \\
\hline (Sumber: Kep-MENLH N0.115 tahun 2003)
\end{tabular}

Pengambilan sampel sedimen mangrove dilakukan secara representatif pada dua stasiun, yaitu dekat outlet pembuangan limbah cair (Stasiun A) dan dekat muara (Stasiun B). Selanjutnya dilakukan analisa kandungan nitrogen $(\mathrm{N})$ dan fosfor $(\mathrm{P})$ pada sampel sedimen tersebut, dengan menggunakan dua acuan metode, yaitu USEPA SW 846 METHOD 3050 B-2000 SNI 06 6989.30-2005 digunakan untuk uji nitrogen dan USEPA SW 846 METHOD 3050 B-2600 APHA 4500 P-E, Ed.22, 2012 digunakan untuk uji fosfor.

Dalam penelitian ini juga dilakukan pengamatan vegetasi mangrove di lokasi pengambilan sampel sedimen. Pengamatan ini dilakukan untuk mengetahui kondisi kerapatan, dominansi, persentase tutupan, dan indeks nilai penting vegetasi mangrove di lokasi penelitian. 
Analisis kerapatan mangrove dihitung sebagai perbandingan dari jumlah individu dengan luas seluruh plot penelitian, kemudian dikonversi menjadi per satuan hektar dengan dikalikan dengan 10.000. Sedangkan dominansi merupakan perbandingan antara jumlah individu dalam suatu spesies dengan jumlah total individu dalam seluruh spesies.

Persentase tutupan mangrove dihitung dengan menggunakan metode hemisperichal photography. Metode ini menggunakan kamera dengan lensa fish eye dengan sudut pandang $180^{\circ}$ pada satu titik pengambilan foto (Jenning et al., 1999; Korhonen et al., 2008 dalam Wayan dan Pramudji, 2014). Konsep dari analisis ini adalah pemisahan pixel langit dan tutupan vegetasi, sehingga persentase jumlah pixel tutupan vegetasi mangrove dapat dihitung dalam analisis gambar biner (Ishida 2004, Chianucci et al., 2014 dalam Wayan dan Pramudji, 2014). Selanjutnya, nilai penting adalah perkiraan pengaruh atau pentingnya suatu spesies tanaman dalam suatu komunitas. Nilai penting adalah penjumlahan dari kerapatan relatif, frekuensi relatif, dan penutupan relatif.

Nilai kerapatan dalam satuan individu/ha dan persentase tutupan dalam satuan persen (\%) selanjutnya digunakan untuk menggambarkan status kondisi vegetasi mangrove. Kondisi ini dikategorikan menjadi tiga, yaitu jarang, sedang dan padat berdasarkan Keputusan Menteri Lingkungan Hidup No. 201 tahun 2004 tentang Kriteria Baku dan Pedoman Penentuan Kerusakan Mangrove seperti ditunjukkan pada Tabel 2.

Tabel 2. Standar baku kerusakan hutan mangrove

\begin{tabular}{llll}
\hline Kriteria & & \%Tutupan & Kerapatan* \\
\cline { 3 - 4 } Baik & Padat & $>75 \%$ & $>1500$ \\
& Sedang & $50 \%-75 \%$ & $1000-1500$ \\
Rusak & Jarang & $<50 \%$ & $<1000$ \\
\hline
\end{tabular}

* dalam individu/hektar

(Sumber: Kep-MENLH No. 201 tahun 2004)

\section{HASIL DAN PEMBAHASAN}

\section{Kualitas Air Sungai Kalimireng}

Berdasarkan kelasnya Sungai Kalimireng masuk dalam kelas III, yaitu air yang peruntukannya dapat digunakan untuk pembudidayaan ikan air tawar, peternakan, air untuk mengairi tanaman, dan atau peruntukan lain yang mempersyaratkan mutu air yang sama dengan kegunaan tersebut. Hasil pengukuran parameter kualitas air pada setiap stasiun di lokasi penelitian ditunjukkan pada Tabel 3 .

Tabel 3. Parameter kualitas air Sungai Kalimireng

\begin{tabular}{lccccc}
\hline & Satuan & \multicolumn{3}{c}{ Stasiun } & Baku \\
\cline { 3 - 5 } & & $\mathbf{1}$ & $\mathbf{2}$ & $\mathbf{3}$ & \\
\hline Suhu & ${ }^{\circ} \mathrm{C}$ & 32.2 & 32.2 & 32.1 & - \\
\hline TSS & $\mathrm{mg} / \mathrm{L}$ & 24.82 & 24.78 & 25.43 & 400 \\
\hline TDS & $\mathrm{mg} / \mathrm{L}$ & 2437 & 2407 & 2437 & 1000 \\
\hline $\mathrm{pH}$ & - & 8.5 & 9 & 8 & $6-9$ \\
\hline DO & $\mathrm{mg} / \mathrm{L}$ & 5.60 & 4.5 & 4.46 & 3 \\
\hline BOD & $\mathrm{mg} / \mathrm{L}$ & 2.01 & 1.89 & 0.84 & 6 \\
\hline COD & $\mathrm{mg} / \mathrm{L}$ & 103.5 & 100.1 & 82.1 & 50 \\
\hline
\end{tabular}

(Sumber: olah data, 2018)

a. Suhu

Nybakken (1988) dalam Wijayanti (2007) menjelaskan bahwa suhu merupakan salah satu faktor yang sangat penting dalam mengatur proses kehidupan dan penyebaran organisme. Berdasarkan hasil pengukuran yang dilakukan, suhu rata-rata permukaan perairan Sungai Kalimireng di sekitar pabrik tepung ikan adalah $32^{\circ} \mathrm{C}$. Hal ini menunjukkan tingkat persebaran suhu yang sama di setiap stasiun. Suhu yang relatif tinggi di perairan ini selain dikarenakan air mendapatkan panas dari suhu udara (radiasi matahari), juga dimungkinkan dari bahan-bahan pencemar yang dapat meningkatkan suhu.

\section{b. Padatan Tersuspensi (TSS)}

Berdasarkan hasil pengukuran selama pengamatan dilakukan, nilai TSS pada lokasi penelitian berkisar antara 24,78 - 25,43 mg/L. Kandungan TSS di Sungai Kalimireng ini masih berada di bawah baku mutu kadar TSS untuk kualitas air kelas III berdasarkan Peraturan Pemerintah Nomor 82 Tahun 2001 sebesar 400 mg/L. Kondisi ini kemungkinan dikarenakan pengambilan sampel air dilakukan saat daerah aliran sungai mengalami surut yang menyebabkan buangan limbah tepung ikan banyak terbawa arus ke arah muara.

\section{c. Padatan Terlarut (TDS)}

Nilai TDS perairan sangat dipengaruhi oleh pelapukan batuan, limpasan dari tanah, dan pengaruh antropogenik yang dapat berasal dari limbah domestik dan industri. Berdasarkan hasil pengukuran kualitas air selama pengamatan yang dilakukan, nilai TDS di lokasi penelitian berkisar antara 2347 $2437 \mathrm{mg} / \mathrm{L}$, sedangkan baku mutu kadar TDS 
untuk kualitas air kelas III berdasarkan Peraturan Pemerintah Nomor 82 Tahun 2001 adalah sebesar $1000 \mathrm{mg} / \mathrm{L}$. Dengan demikian kandungan TDS di Sungai Kalimireng ini tidak memenuhi baku mutu yang telah ditetapkan.

\section{d. $\mathrm{pH}$}

Berdasarkan Peraturan Pemerintah Nomor 82 Tahun 2001, baku mutu untuk pH kualitas air kelas III adalah sebesar 6 - 9. Hasil pengukuran menunjukkan rata-rata $\mathrm{pH}$ perairan di lokasi penelitian masih berada pada rentang baku mutu yang ditetapkan. Nilai pH perairan pada Stasiun 1, 2, dan 3 masing-masing adalah 8,5, 9 dan 8. Nilai $\mathrm{pH}$ yang lebih tinggi pada Stasiun 2 dapat disebabkan karena stasiun tersebut merupakan outlet limbah tepung ikan.

\section{e. Oksigen Terlarut (DO)}

Oksigen terlarut merupakan parameter penting untuk mengetahui kualitas suatu perairan. Tanpa oksigen terlarut maka tidak akan ada kehidupan di perairan (Fatimah, 2006). Kadar oksigen terlarut rendah akan menimbulkan bau tidak sedap akibat terjadi degradasi anaerobik yang mungkin terjadi (Suriwiria, 1996 dalam Fatimah, 2006).

Berdasarkan hasil pengukuran selama pengamatan dilakukan, konsentrasi DO berkisar antara 4,46 - 5,60 mg/L. Nilai ini masih memenuhi baku mutu kualitas air kelas III berdasarkan Peraturan Pemerintah Nomor 82 Tahun 2001.

\section{f. Chemical Oxygen Demand (COD)}

Nilai COD merupakan ukuran pencemaran oleh zat - zat organik yang secara alamiah dapat dioksidasi melalui proses biologis sehingga menyebabkan berkurangnya oksigen terlarut dalam perairan. Berdasarkan hasil pengukuran yang dilakukan, COD di perairan Sungai Kalimireng berkisar antara 82,1 - 103,5 $\mathrm{mg} / \mathrm{L}$. Hal ini menunjukkan bahwa kandungan COD di Sungai Kalimireng tidak memenuhi baku mutu kualitas air kelas III berdasarkan Peraturan Pemerintah Nomor 82 Tahun 2001 sebesar $50 \mathrm{mg} / \mathrm{L}$.

\section{g. Biological Oxygen Demand (BOD)}

BOD menyatakan jumlah oksigen yang diperlukan untuk mengoksidasi bahan organik dalam air. Semakin besar konsentrasi BOD mengindikasikan bahwa perairan p-ISSN: 2460-8815, e-ISSN: 2549-1652 tersebut telah tercemar karena semakin banyak zat organik yang mencemari perairan. Berdasarkan Peraturan Pemerintah Nomor 82 Tahun 2001, baku mutu kadar BOD untuk kualitas air kelas III adalah sebesar $6 \mathrm{mg} / \mathrm{L}$.

Hasil pemeriksaan di laboratorium menunjukkan jumlah BOD pada Stasiun 1, 2, dan 3 masing-masing adalah sejumlah 2,01 mg/L, 1,89 mg/L, dan 0,84 mg/L. Kandungan BOD di sungai Kalimireng ini masih memenuhi baku mutu kualitas air kelas III.

\section{Status Mutu Air Sungai Kalimireng}

Kondisi Sungai Kalimireng ditinjau dari parameter TSS bernilai 0,05 yang berarti memenuhi baku mutu, TDS bernilai 8 yang berarti tercemar sedang, dan $\mathrm{pH}$ bernilai 2 yang berarti tercemar ringan. Sedangkan parameter DO bernilai 0,2 yang berarti memenuhi baku mutu, BOD bernilai 0,3 yang berarti memenuhi baku mutu, dan COD bernilai 6 yang berarti tercemar sedang.

Terlihat dari enam parameter yang diukur terdapat satu parameter dengan status tercemar ringan yaitu parameter $\mathrm{pH}$, dua parameter dengan status tercemar sedang yaitu TDS dan COD, serta tiga parameter yang memenuhi baku mutu perairan yaitu TSS, DO, BOD. Hasil perhitungan nilai Indeks Pencemaran perairan Sungai Kalimireng selengkapnya ditunjukkan pada Tabel 4 .

Tabel 4. Nilai indeks pencemaran (IP) perairan Sungai Kalimireng

\begin{tabular}{lccl}
\hline Par & IP & Kategori & Status Mutu Air \\
\hline TSS & 0.05 & $0-1.0$ & Good \\
TDS & 8 & $5.0-10$ & cemar sedang \\
pH & 2 & $1.0-5$ & cemar ringan \\
DO & 0.2 & $0-1.0$ & Good \\
BOD & 0.3 & $0-1.0$ & Good \\
COD & 6 & $5.0-10$ & cemar sedang \\
\hline
\end{tabular}

(Sumber: olah data, 2018)

\section{Kandungan Unsur Hara di Sedimen Mangrove Sungai Kalimireng}

Hasil pengukuran kandungan nitrogen $(\mathrm{N})$ dan fosfor (P) di sedimen mangrove Sungai Kalimireng ditunjukkan pada Tabel 5. Kandungan nitrogen pada sedimen mangrove di Stasiun A dan B masing-masing adalah $0,766 \mathrm{mg} / \mathrm{g}$ dan $0,359 \mathrm{mg} / \mathrm{g}$. Sedangkan Kandungan fosfor pada sedimen mangrove di Stasiun A dan B masing-masing adalah 0,131 $\mathrm{mg} / \mathrm{g}$ dan $0,0769 \mathrm{mg} / \mathrm{g}$. Hal ini menunjukkan bahwa sampel sedimen yang diambil di 
Stasiun A memiliki kandungan nitrogen dan fosfor yang lebih tinggi dibanding dengan sampel sedimen yang diambil di Stasiun B.

Tabel 5. Kandungan unsur hara nitrogen (N) dan fosfor

(P) di sedimen mangrove Sungai Kalimireng

\begin{tabular}{ccc} 
Stasiun & $\mathbf{N}(\mathbf{m g} / \mathbf{g})$ & $\mathbf{P}(\mathbf{m g} / \mathbf{g})$ \\
\hline $\mathrm{A}$ & 0,766 & 0,131 \\
$\mathrm{~B}$ & 0,359 & 0,0769 \\
\hline
\end{tabular}

(Sumber; olah data, 2018)

\section{Struktur Komunitas Mangrove}

Hasil analisis vegetasi mangrove di lokasi penelitian secara umum ditunjukkan pada Tabel 6.

Tabel 6. Nilai Kerapatan, Dominasi, Persentase tutupan,

INP

\begin{tabular}{|c|c|c|c|c|c|}
\hline St & Ienis & Kerapatan & Dominansi & \%tutupan & $\underline{\text { INP }}$ \\
\hline A & A.marina & 700 & 100 & $68,3 \%$ & 300 \\
\hline B & A.marina & 1566,69 & 100 & $79 \%$ & 300 \\
\hline
\end{tabular}

a. Keanekaragaman

Hasil pengamatan pada dua stasiun menunjukkan bahwa secara umum vegetasi mangrove yang ada di kawasan Sungai Kalimireng termasuk dalam kategori kurang beragam. Pada kawasan tersebut hanya ditemukan spesies Avicennia marina. Spesies ini biasa disebut masyarakat setempat dengan api-api atau bogem. Sebagai bagian dari komunitas hutan mangrove, pohon api-api biasanya tumbuh di tepi atau dekat laut. Mangrove jenis ini ditemukan pula tumbuh di rawa-rawa air tawar, tepi pantai berlumpur daerah mangrove, hingga di substrat yang berkadar garam sangat tinggi (Anonim, 2011). Hal ini disebabkan karena jenis tanaman A. marina toleran terhadap salinitas sangat tinggi, memiliki kemampuan menempati dan tumbuh pada berbagai habitat pasang-surut.

Dari beberapa hasil penelitian diketahui bahwa A. marina dapat tumbuh pada substrat yang berpasir kasar, halus maupun lumpur yang dalam (Kusmana et al., 2003 dalam Halidah dan Kama, 2013). Jenis A. marina tumbuh pada ketinggian 0-50 m dari permukaan laut, memiliki tekstur ringan dan tumbuh pada tapak yang berlumpur dalam, tepi sungai, daerah kering dengan temperatur berkisar $29-30^{\circ} \mathrm{C}$. Kondisi ini serupa dengan parameter lingkungan pada kedua stasiun. Vegetasi mangrove yang ada di kawasan sungai Kalimireng ini hanya tumbuh pada daerah intertidal. Kondisi seperti ini sesuai dengan pernyataan Bengen (2003) bahwa pada umumnya mangrove tumbuh pada daerah intertidal.

b. Kerapatan

Berdasarkan hasil pengukuran didapatkan bahwa kerapatan mangrove di kedua stasiun memiliki perbedaan yang cukup signifikan, seperti ditunjukkan pada Gambar 1. Kerapatan mangrove di Stasiun A, lokasi dekat dengan pembuangan limbah cair tepung ikan, adalah 700 pohon/ha sedangkan kerapatan mangrove di Stasiun B, lokasi dekat dengan muara, adalah 1566,68 pohon/ha.

Berdasarkan Keputusan Menteri Lingkungan Hidup No. 201 tahun 2004, maka kondisi kerapatan vegetasi mangrove di Stasiun A tergolong dalam kondisi yang jarang dan rusak $(<1000$ pohon/ha). Sedangkan kondisi vegetasi mangrove di stasiun B tergolong dalam kondisi yang padat dan baik (>1500 pohon/ha).

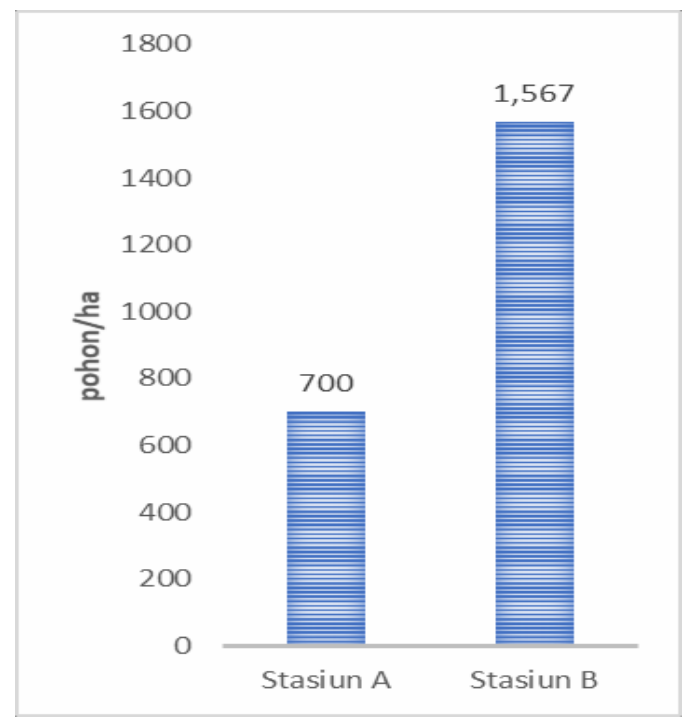

Gambar 1. Kerapatan mangrove di lokasi penelitian (Sumber; olah data, 2018)

\section{c. Dominansi}

Dominansi memberikan gambaran tentang penguasaan jenis dalam plot. Pada stasiun A dan $B$ didominasi penuh dengan mangrove jenis Avicennia marina. Hal ini disebabkan jenis Avicennia marina mampu berkompetisi dengan baik untuk memperoleh unsur hara dari jenis mangrove lain. Selain itu jenis Avicennia marina tumbuh pada kondisi lingkungan yang mendukung keberhasilan hidup jenis Avicennia marina. Apabila ukuran batang semakin besar maka akan memperluas dominansinya. 
Menurut Harahab (2010) bahwa jenis yang memiliki nilai dominansi yang relatif rendah berarti mencerminkan ketidakmampuannya menoleransi kondisi lingkungan. Hal ini menunjukkan bahwa jenis mangrove Avicennia marina di lokasi penelitian toleran dan mampu bertahan terhadap karakter limbah yang dihasilkan dari pabrik tepung ikan.

\section{d. \% Tutupan}

Dari hasil perhitungan yang dilakukan, persentase penutupan mangrove di stasiun $\mathrm{A}$ dan B memiliki perbedaan yang cukup signifikan. Persentase tutupan mangrove di Stasiun A adalah 68,3\%, sedangkan persentase tutupan mangrove pada stasiun B adalah 79\%. Tingkat persentase tutupan mangrove di kedua stasiun ditunjukkan pada Gambar 2.

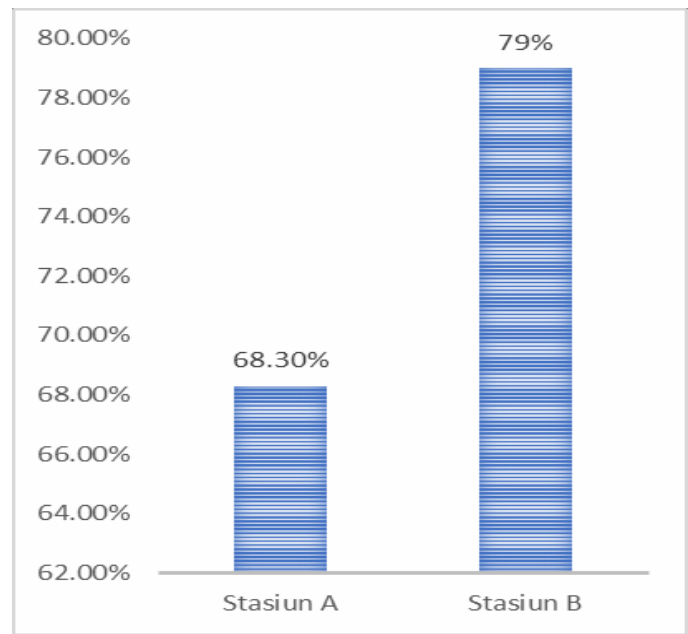

Gambar 2. Persentase tutupan mangrove di lokasi penelitian (Sumber; olah data, 2018)

\section{Diskusi}

Menurut Murtidjo (2001) dalam Ginanjar (2016) tepung ikan mengandung mineral kalsium dan fosfor serta vitamin B kompleks khususnya vitamin B12. Hal ini menyebabkan fosfor dalam sedimen mangrove di Stasiun A, yang dekat dengan pembuangan limbah cair tepung ikan, lebih tinggi dibanding dengan sedimen di Stasiun B, yang berada di dekat muara.

Demikian juga dengan kandungan nitrogen pada sedimen mangrove di Stasiun A yang lebih tinggi dibanding dengan Stasiun B. Kondisi ini juga diduga dikarenakan lokasi Stasiun A yang berdekatan dengan pembuangan limbah cair tepung ikan sehingga bahan-bahan organik sisa p-ISSN: 2460-8815, e-ISSN: 2549-1652 pengolahan tepung ikan banyak mengendap pada sedimen mangrove di Stasiun A. Menurut Ibrahim (2005) dalam Ginanjar (2005), dalam beban cemaran organik yang tinggi terkandung pula senyawa nitrogen yang tinggi yang merupakan protein larut air setelah mengalami leaching selama pencucian, defrost dan proses pemasakan.

Kondisi vegetasi mangrove di Stasiun A kurang baik apabila dibandingkan dengan mangrove di stasiun $B$. Hal ini terlihat dari kerapatannya yang jarang $(<1000$ pohon/ha) sementara mangrove Stasiun B dalam kondisi padat dan baik ( $>1500$ pohon/ha). Demikian juga dengan tutupan mangrove pada Stasiun A $(68,3 \%)$ yang lebih rendah dibandingkan dengan tutupan mangrove pada stasiun B (79\%) .

Hal ini dapat disebabkan unsur fosfor dan nitrogen yang berlebih di Stasiun A yang berdekatan dengan lokasi pembuangan limbah cair tepung ikan. Kelebihan unsur fosfor bagi tanaman dapat menghambat pertumbuhan tanaman karena terjadinya ikatan N-P yang menyulitkan tanaman menyerap unsur nitrogen. Selanjutnya menurut Liferdi (2009), kadar fosfor yang tinggi dalam sedimen dapat menghambat pertumbuhan tanaman, kerusakan pada daun dan akar bahkan kematian pada tumbuhan.

Hal ini juga didukung dengan morfologi mangrove jenis $A$. marina yang memiliki akar napas, yakni akar percabangan yang tumbuh dengan jarak teratur secara vertikal dari akar horizontal yang terbenam di dalam tanah, sehingga dapat memerangkap sisa-sisa pembuangan limbah tepung ikan yang dihasilkan dari proses pencucian dan pemasakan.

\section{KESIMPULAN}

Parameter kualitas air Sungai Kalimireng yang memenuhi baku mutu berdasarkan Peraturan Pemerintah Nomor 82 Tahun 2001 untuk kualitas air kelas III adalah pH, TSS, DO, dan BOD. Sementara parameter TDS dan COD tidak memenuhi baku mutu yang telah ditetapkan. Kondisi tersebut dapat dipengaruhi oleh masukan limbah cair pengolahan tepung ikan. Status indeks pencemaran Sungai Kalimireng dikategorikan sebagai pencemaran ringan dengan nilai indeks pencemaran kualitas air 0,05 - 8. Dari nilai indeks pencemaran tersebut maka diperlukan pengendalian pencemaran 
perairan Sungai Kalimireng, terutama untuk meminimalisir jumlah TDS dan COD, agar dapat dimanfaatkan sesuai peruntukannya dan menjaga agar kualitas air sungai Kalimireng tetap sesuai dengan mutu air sasaran yaitu kriteria mutu air kelas III menurut Peraturan Pemerintah Nomor 82 Tahun 2001.

Dari tinjauan ekosistem mangrove, kandungan nitrogen dan fosfor di sedimen mangrove pada stasiun dekat pembuangan limbah tepung ikan lebih tinggi dibanding sedimen pada stasiun dekat muara. Kondisi ini disebabkan oleh bahan-bahan organik yang berasal dari pembuangan limbah tepung ikan. Hal tersebut berdampak pada kerapatan dan \%tutupan mangrove pada stasiun dekat muara lebih baik daripada mangrove di stasiun dekat pembuangan limbah tepung ikan. Stasiun dekat muara memiliki nilai kerapatan sejumlah 1566,67 pohon/ha dan \% tutupan $79 \%$, yang berarti dalam kondisi baik padat. Sedangkan mangrove pada stasiun dekat pembuangan limbah cair memiliki nilai kerapatan sejumlah 700 pohon/ha yang berarti rusak jarang dan \%tutupan 68.3\% yang berarti sedang.

\section{DAFTAR PUSTAKA}

Anonim. 2011. Keluarga bakau yang banyak manfaat. Koran Jakarta Nasional. Diakses tanggal 5 Januari 2011. http://www.bataviase.co.id.

Bengen, Dietrich. 2003. Pedoman Teknis Pengenalan dan Pengelolaan Ekosistem Mangrove. Bogor: PKSL-IPB.

Effendi, Hefni. 2003. Telaah Kualitas Air (Bagi Pengelolaan Sumber Daya dan Lingkungan Perairan). Yogyakarta: Kanisius.

Fatimah. 2006. Pengaruh pengolahan limbah tekstil PT. APAC INTI CORPORA (AIC) terhadap kualitas air Sungai Bade Bawen. Skripsi, UNNES Semarang.

Ginanjar. 2016. Degradasi Bahan Organik Limbah Cair Tepung Ikan dengan Penambahan Variasi Konsentrasi Bioaktivator dan Variasi Lama Fermentasi. Skripsi, UIN Maulana Malik Ibrahim Malang.

Halidah dan H. Kama. 2013. Penyebaran alami Avicennia marina (Forsk) Vierh dan Sonneratia Alba (Smith) pada substrat pasir di Desa Tiwoho, Sulawesi Utara. Indonesia Rehabilitation
Forest Journal, 1 (1) 51-58.

Harahab, N. 2010. Penilaian Ekonomi Ekosistem Hutan Mangrove dan Aplikasinya dalam Perencanaan Wilayah Pesisir. Yogyakarta: Graha ilmu.

Irwanto, Robert. 2011. Pengaruh Pembuangan Limbah Cair Industri Tahu terhadap Kualitas Air Sumur di Kelurahan Krobokan Kota Semarang. Skripsi, Universitas Negeri Semarang.

Liferdi, L. 2009. Efek pemberian fosfor terhadap pertumbuhan dan status hara bibit manggis. Jurnal Ilmiah Balai Penelitian Buah Tropika, Bogor.

Wayan, I. dan Pramudji. 2014. Panduan Monitoring Status Ekosistem Mangrove. Jakarta: Lembaga Ilmu Pengetahuan Indonesia (LIPI).

Wijayanti, Henni M. 2007. Kajian Kualitas Perairan di Pantai Kota Bandar Lampung Berdasarkan Komunitas Makrobenthos. Tesis, Program Pascasarjana UNDIP Semarang. 